\author{
JURNAL HUKUM
}

\title{
PARA-PARA ADAT SEBAGAI LEMBAGA PERADILAN ADAT PADA MASYARAKAT HUKUM ADAT PORT NUMBAY DI KOTA JAYAPURA
}

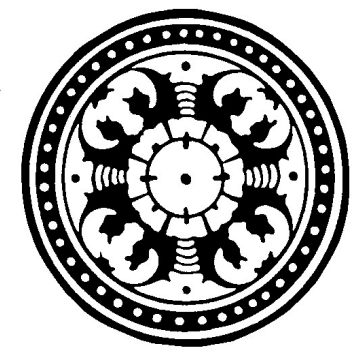

SARA IDA MAGDALENA AWI

PROGRAM PASCASARJANA

UNIVERSITAS UDAYANA

DENPASAR

2012 


\title{
PARA-PARA ADAT SEBAGAI LEMBAGA PERADILAN ADAT PADA MASYARAKAT HUKUM ADAT PORT NUMBAY DI KOTA JAYAPURA
}

\author{
oleh \\ Sara Ida Magdalena Awi \\ Mahasiswa Magister Ilmu Hukum Unud
}

\begin{abstract}
customary settlement resolved through the para-para adat as judicial institution indigenous peoples as Port Numbay here acts as a facilitator and mediator in resolving criminal matters and civil indigenous peoples. Fines and penalties as traditional instruments and settlement alternatives in indigenous communities and tribal peoples Port Numbay in Jayapura, where settlement through customary lighter sanction than upon completion via the national law so that indigenous people prefer Nafri resolve the issue through traditional institutions than through national law. While the obstacles encountered in the judicial settlement through customary Port Numbay is sometimes a delay the trial because of the absence of one of the parties to the dispute that is the perpetrator, due to illness, the actor did not want other people to intervene in problem solving, as well as evidence of the witnesses and the constraints of victims so that can complicate settlement through customary court.

It is suggested that indigenous institutions Port Numbay to be more actively involved in efforts to resolve the criminal case custom case, given the indigenous people in the city of Jayapura Port Numbay more familiar way of resolving the problem through customs. And to indigenous Port Numbay in Jayapura to always support the existence of the court or agency of indigenous peoples Nafri in solving the problems of traditional criminal and civil customs in order to achieve the security and welfare of indigenous peoples in Port Numbay.
\end{abstract}

Keywords: Judicial Custom, Para-Para Adat, Custom Case, Indigenous Peoples Port Numbay.

\section{PENDAHULUAN}

\section{Latar Belakang Masalah}

Masyarakat adat Port Numbay

mengenal dualisme sistem

pemerintahan yakni pemerintahan formal dan pemerintahan non

formal. Pemerintahan formal yaitu

sistem pemerintahan yang

terstruktur dalam sistem

pemerintahan Negara Kesatuan 
Republik Indonesia yang bersifat konstitusional yang dikepalai oleh seorang kepala kampung beserta perangkatnya. ${ }^{1} \quad$ Sedangkan pemerintahan non formal merupakan sistem pemerintahan asli atau pemerintahan adat. Dalam sistem pemerintahan adat pada masyarakat hukum adat Port Numbay dipimpin oleh seorang ondoafi beserta aparatusnya. Dalam sistem ini yang dikedepankan adalah musyawarah untuk mufakat, dan dari praktek ondoafi ini tercemin bahwa sistem demokrasi sudah merupakan bagian dari praksis kehidupan masyarakat adat di Port Numbay. ${ }^{2}$

Dalam menjalankan kekuasaan adat, ondoafi dibantu oleh seorang penasehat dalam kampung yang berfungsi untuk mengawasi, memelihara, dan melaksanakan hukum adat. Untuk

\footnotetext{
${ }^{1}$ H. Nurcholis, 2005, Teori dan Praktek Pemerintahan Otonomi Daerah, Grasindo, Jakarta, hlm. 138

2 Elly Waicang, 2002, Sistem Pemerintahan Adat dan Lokal Di Indonesia: Peluang dan Tantangan, Aliansi Masyarakat Adat Nusantara (AMAN), Jakarta, hlm 18
}

jabatan kepala suku, itu dianggap yang tertua dalam keluarga. Hal ini berarti dalam setiap jabatan yang disandang merupakan warisan turun temurun dari generasi yang tua kepada generasi yang baru dan masih mempunyai hubungan darah dalam struktur lembaga adat kampung. ${ }^{3} \quad$ Meskipun jabatan ondoafi bersifat turun temurun dan tidak dapat digantikan oleh garis keturunan lain, namun proses pemilihan ondoafi serta proses melahirkan keputusan dalam forum ondoafi mencerminkan proses demokrasi. Artinya, partisipasi dan suara masyarakat adat dari suku tersebut menetukan hasil proes tersebut melalui perwakilan mereka, yang pada umunya juga bersifat turun temurun. ${ }^{4}$

Pada masyarakat adat Port Numbay terdapat silsilah otoritas keOndoafian dan memiliki suatu tempat penyelesaian masalah adat yang sering disebut dengan istilah "Para-Para Adat". Para-para adat

3 Wiklif Yarisetou, Tiatiki, Konsep dan Praktek, Arika Publisher, Jayapur, hlm. 136.

${ }^{4}$ Ibid, hlm 18-19 
adalah suatu tempat pertemuan

untuk bermusyawarah maupun menyelesaikan sengketa adat baik itu sengketa adat pidana maupun sengketa adat perdata. Para-para adat ini memiliki beberapa fungsi yakni fungsi sosial, fungsi adat dan fungsi peradilan. Dimana di dalam penelitian ini akan difokuskan yaitu para-para adat yang berfungsi sebagai suatu lembaga peradilan dalam suatu masyarakat hukum adat. Para-para adat dikepalai oleh seorang kepala adat dan gelar yang digunakan antara kampung satu dengan kampung lain ada persamaan dan perbedaan. Perbedaanya karena pengaruh dari ragam bahasa dan jenis bahasa daerah yang digunakan oleh sukusuku di Port Numbay.

Peranan ondoafi sangat penting dalam penyelesaian sengketa adat karena itu semua merupakan kewenangan dari kepala adat tersebut. Seorang kepala adat Ondoafi mempunyai kekuasaan, kewenangan mengatur, penyelenggaraan dan peruntukan atas sengketa adat. Dengan demikian para-para adat merupakan suatu media penyelesaian sengketa yang bertindak dalam menjalankan fungsinya sebagai lembaga peradilan adat. Sebagai suatu kesatuan masyarakat hukum adat yang hidup dan tumbuh di tengahtengah masyarakat, mereka diperhadapkan dengan berbagai pilihan dalam proses penyelesaian sengketa. Baik melalui jalur litigasi maupun non litigasi. Penyelesaian sengketa melalui jalur non litigasi pada masyarakat hukum adat Port Numbay di kenal dengan istilah "Para-Para Adat", yaitu proses penyelesaian sengketa secara kekeluargaan sehingga diantara para pihak yang bersengketa hubungan kekeluargaan tetap terjaga dan harmonis.

Peradilan adat di Papua diatur berdasarkan Peraturan Khusus Propinsi Papua Nomor 20 Tahun 2008 tentang Peradilan Adat Papua (yang selanjutnya disebut Perdasus Peradilan Adat). Perdasus ini adalah pelaksanaan dari Undang-undang Nomor 21 Tahun 2001 tentang Pemberian Otonomi Khusus Bagi Propinsi Papua (yang selanjutnya disebut undang-undang Otsus). 
Pengakuan dan Penghormatan tersebut tidak hanya terhadap identitas sosial budaya, tetapi juga terhadap eksistensinya sebagai subjek hukum. Hal ini ditegaskan dalam pasal 18B Ayat (2) UUD 1945 yang menyatakan bahwa negara mengakui dan menghormati kesatuan-kesatuan masyarakat hukum adat beserta hak-hak tradisionalnya sepanjang masih hidup dan sesuai dengan perkembangan masyarakat dan prinsip Negara Kesatuan Republik Indonesia (yang selanjutnya disebut NKRI), yang diatur dalam undangundang. ${ }^{5}$ Jaminan konstitusional merupakan dasar hukum yang sangat kuat bagi kesatuan masyarakat hukum adat. Namun, untuk dapat tetap bertahan dan eksis tentu diperlukan upaya revitalisasi, baik oleh negara melalui instrumen hukum, upaya secara akademis, maupun upaya nyata terhadap

5 Moh. Mahfud. MD, 2010, Revitalisasi Masyarakat Hukum Adat Dalam Kerangka UUD 1945 Menyongsong Globalisasi, Seminar Awig-Awig II, Bali, 30 September 2010, hlm. 4 kesatuan masyarakat hukum adat itu sendiri.

Salah satu kekhususan otonomi bagi Provinsi Papua adalah adanya penyelenggaraan pengadilan adat sebagaimana tercantum dalam Pasal 50 ayat (2) dan Pasal 51 ayat (1) sampai dengan ayat (8) UU Otsus. Pada kenyataannya kehidupan masyarakat adat di Papua masih terus memberlakukan, mempertahankan dan tunduk pada pengadilan adatnya masing-masing terutama dalam penyelesaian perkara adat yang terjadi diantara sesama warga masyarakat hukum adat. Kenyataan ini makin diperkuat dengan pengaturannya dalam Perdasus Peradilan Adat.

Berangkat dari uraianuraian latar belakang diatas, bahwa sudah saatnya dilakukan penelitian yang mendalam untuk mengkaji secara kritis mengenai pelaksanaan fungsi lembaga peradilan adat. Dimana penelitian ini harus dilakukan secara menyeluruh, baik menyangkut aspek normatif dari lembaga peradilan adat, juga menyangkut aspek empiriknya, 
yaitu bagaimana para-para adat menjalankan fungsinya sebagai lembaga peradilan adat tersebut dalam kenyataan. Hal inilah yang mendorong penulis tertarik untuk menyusun sebuah tesis dengan judul "Para-Para Adat Sebagai Lembaga Peradilan Adat Pada Masyarakat Hukum Adat di Kota Jayapura”.

2. Rumusan Masalah

Berdasarkan uraian latar belakang masalah sebagaimana yang telah diuraikan diatas, maka dapat dirumuskan beberapa masalah sebagai berikut :

a. Bagaimanakah para-para adat melaksanakan fungsinya sebagai lembaga peradilan adat didalam masyarakat adat Port Numbay?

b. Bagaimanakah efektifitas parapara adat dalam melaksanakan fungsi peradilan adat dalam masyarakat adat Port Numbay di Kota Jayapura?

3. Tujuan

Untuk memberikan sumbangan konseptual mengenai pelaksanaan fungsi para-para adat sebagai lembaga peradilan adat di kaitkan dengan kondisi dualisme pemerintahan kampung yang kini berlaku di Papua. Selain itu juga untuk memberikan sumbangan konseptual mengenai lembaga penyelesaian sengketa di luar pengadilan yang lebih di kenal dengan istilah "para-para adat".

\section{METODE PENELITIAN}

Penelitian ini termasuk jenis penelitian dengan aspek empiris (penelitian hukum empiris) yang oleh R. Jones disebut nondoctrinal research atau oleh Soentandyo Wignjosoebroto disebut penelitian non doktrinal (socio legal research). ${ }^{6}$ Penelitian ini bersifat deskriptif analitis, di mana data yang di gunakan meliputi data primer dan data sekunder. Pengumpulan data pada penelitian ini di lakukan dengan menggunakan teknik wawancara dan studi kepustakaan.

\section{HASIL DAN PEMBAHASAN}

1. Lembaga Masyarakat Adat Sebagai Pelaksana Fungsi Peradilan

\footnotetext{
${ }^{6}$ Bambang Sunggono, 2003, Metodologi Penelitian Hukum, Rajawali Pers, Jakarta, hlm. 43
} 
Selain masyarakat adat kampung Nafri, keberadaan lembaga masyarakat adat kampung Nafri sangat penting atau dengan kata lain dipandang sangat strategis dalam menjalankan roda pemerintahan adat dalam hal ini yakni yang menjalankan fungsi peradilan adat dalam para-para adat. Dalam pasal 9 ayat (3) Peraturan Daerah Khusus Propinsi Papua No. 20 Tahun 2008 menyebutkan bahwa "penyelenggaraan peradilan adat diurus oleh hakim adat". ${ }^{7}$ Menurut hasil wawancara bersama Bpk. Terianus Awi mengatakan bahwa, lembaga masyarakat adat kampung Nafri merupakan lembaga tertinggi dalam struktur pemerintahan adat pada masyarakat adat kampung Nafri, dimana pengambilan keputusan adat tertinggi berada di tangan Ontofro atau hakim adat.

Masyarakat adat kampung Nafri sebagian besar dalam naungan hukum adat dan norma adat dijadikan pedoman dalam mengatur

${ }^{7}$ Moh. Mahmud, op.cit., hlm. 6 kehidupan sosial. Perkara dimasyarakat ditangani dan diselesaikan melalui lembaga parapara adat yang berfungsi sebagai lembaga peradilan adat yang diakui dan ditaati oleh masyarakat adat kampung Nafri. Para-para adat ini oleh Lawrence M. Friedman dalam teorinya legal system disebut sebagai legal structure. Komponen struktur dari suatu sistem hukum mencakup berbagai lembaga yang diciptakan oleh sistem hukum tersebut dengan berbagai macam fungsi dalam mendukung bekerjanya sistem hukum tersebut. Bersama dengan ini Mochtar juga mengatakan bahwa hukum tidak hanya meliputi asas dan kaidah yang mengatur kehidupan manausia dalam masyarakat, melainkan juga termasuk lembaga dan proses dalam mewujudkan berlakunya kaidah hukum dalam kenyataan di masyarakat. $^{8}$

8 Mochtar Kusumaatmadja, 2002, Konsep-konsep Hukum Dalam Pembangunan, Pusat Studi Wawancara Nusantara Hukum dan Pembangunan bekerjasama dengan penerbit PT. Alumni, Bandung, hlm. 4 
Lembaga masyarakat adat kampung Nafri atau yang sering disebut dewan adat, dengan koomposisi sebagai berikut:

1. Ketua (Ontofro)

\section{a. Ontofro Warke}

: George Arnold Awi

b. Ontofro Sembekra

: Terianus Awi

2. Wakil ketua (Awi)

: Wellianus Taniauw

3. Sekertaris dan Wakil sekertaris : Ellieser Merahabia

4. Kepala-kepala suku (whase ontofro)

2. Kompetensi Para-Para Adat Dalam Menyelesaikan Perkara Adat

$$
\text { Peradilan Adat adalah }
$$
peradilan rakyat di tingkat kampung yang menyelesaikan perkara perselisihan secara damai dan kekeluargaan untuk merukunkan kembali para pihak yang saling bertentangan, dengan sistem musyawarah dan mufakat menurut hukum adat masyarakat bersangkutan. Di kampung Nafri lembaga yang melaksanakan fungsi sebagai peradilan adat adalah parapara adat.

Dalam penyelesaian konflik adat yang sedang dihadapi Ontofro (hakim adat) dengan menggunakan pendekatan hukum adat, dimana ontofro harus berpegang pada tiga asas pokok yaitu asas kerukunan, kepatutan dan keselarasan yang menjadi pedoman dalam mencarikan pemecahan terhadap persoalan adat yang dihadapi ${ }^{9}$. Asas kerukunan adalah suatu asas yang isinya berhubungan erat dengan pandangan dan sikap orang menghadapi hidup bersama dalam lingkungan dengan sesamanya untuk mencapai suasana hidup bersama yang aman, tentram, dan sejahtera. ${ }^{10}$

Asas kepatutan merupakan asas yang menekankan perhatian kepada cara menemukan jawaban tentang bagaimana kualitas suatu perkara dan status para pihak dapat diselamatkan sebaik-baiknya. Pada

\footnotetext{
${ }^{9}$ Moh. Kosnoe, 1978, CatatanCatatan Terhadap Hukum Adat Dewasa Ini, Airlangga University Press, Surabaya, hlm 44.

${ }^{10}$ Ibid
} 
intinya sasaran utama dari asas ini adalah menghindarkan para pihak jatuh kedalam rasa malu. ${ }^{11}$ Dalam penerapan asas kepatutan Ontofro (hakim adat) tidak boleh bersikap kaku, melainkan harus menyesuaikan diri dengan perubahan yang terjadi di masyarakat, karena apa yang dianggap patut di masa lalu belum tentu dianggap patut di masa kini.

Asas keselarasan adalah asas yang berkaitan dengan cara bagaimana melihat suatu persoalan itu secara bijaksana, sehingga pemecahan yang diberikan dapat diterima oleh para pihak dan masyarakat sebagai suatu yang melegakan perasaan. Sasaran utama dari asas ini adalah supaya para pihak dan masyarakat dapat menerima dan merasa puas terhadap pemecahan yang diberikan.

Mengenai perkara-perkara yang terjadi di kampung Nafri sangat bervariasi, demikian pula sanksi yang dijatuhkan juga sangat

11 I Nyoman Sirtha, 2008, Aspek Hukum Dalam Konflik Adat di Bali, Udayana University Press, Denpasar, hlm. 80 bervariasi. Secara umum perkaraperkara yang terjadi dalam kampung Nafri dapat dikwalifikasikan menjadi dua jenis, yaitu berupa pelanggaran adat dan berupa sengketa. Di samping pelanggaran hukum adat, Ontofro juga menangani perkara yang berupa sengketa. Sengketa dapat terjadi karena adanya konflik antara dua atau lebih pihak akibat ketidak sesuaian yang menyangkut nilainilai, perbedaan pendapat maupun perbedaan kepentingan.

Berkaitan dengan kasus pelanggaran hukum adat dan sengketa yang ditangani oleh parapara adat ternyata cukup beragam. Keragaman obyek yang menjadi sumber konflik yang terjadi di kampung Nafri tersebut dapat dikwalifikasikan dalam dua kelompok besar yaitu perkara yang berlatar belakang masalah adat murni dan perkara yang berlatar belakang campuran. Perkara yang berlatar belakang masalah adat murni yaitu suatu perkara yang berkaitan erat dengan adat. Sedangkan perkara yang berlatar belakang masalah campuran adalah 
suatu perkara yang terkaitan erat dengan pelanggaran hukum adat juga melanggar hukum lainnya. Di kampung Nafri, sengketa yang paling banyak terjadi dan diselesaikan oleh Ontofro sebagai Hakim Perdamaian Adat adalah perkara antara individu melawan individu, seperti kasus perkelahian, penganiayaan, kekerasan dalam rumah tangga dan kasus tanah

3. Proses Penyelesaian Perkara Adat Penyelesaian perkara adat yang mengakibatkan terganggunya keseimbangan keluarga dan masyarakat walaupun adakalanya perkaranya sampai ditangani oleh alat negara dapat ditempuh dengan cara melalui pribadi dan atau keluarga yang bersangkutan, perkumpulan dan organisasi.

Begitu pula dengan perkaraperkara adat atau yang dikenal oleh masyarakat adat merupakan pelanggaran adat, yang terjadi di masyarakat adat kampung Nafri. Seiring dengan makin banyaknya perkara-perkara adat yang timbul di kalangan masyarakat adat kampung Nafri maka masyarakat kampung
Nafri melalui 2 (dua) keondoafiannya baik dari arah Barat yaitu Warke dan Timur yaitu Sembekra beserta kepala-kepala suku membentuk suatu pengadilan adat atau lembaga adat yang dimana dipercayakan sebagai suatu lembaga yang setingkat dengan pengadilan resmi (pengadilan negara) untuk menyelesaikan semua perkara pidana adat maupun sengketa perdata adat yang terjadi di masyarakat adat kampung Nafri.

Di dalam penyelesaian perkaraperkara pidana dan perdata posisi duduk juga menentukan dalam sidang adat, adapun posisinya duduknya sebagai berikut :

1. Ada 3 (tiga) orang yang berhak duduk di meja utama atau pimpinan:
a. Ketua (ontofro) posisi duduknya di tengah
b. Wakil ketua (awi) posisi duduknya di kanan
c. Sekertaris posisi duduknya di kiri 
2. Pelaku dan korban dihadapkan di meja pimpinan dan dipisahkan tempat duduknya kiri dan kanan.

3. 2 (dua) Pesuruh besar dari ontofro warke dan sembekra mendampingi pelaku dan korban, mereka dilindungi oleh ke 2 pesuruh besar tersebut. Tujuannya kalau ada perkelahian antara pelaku dan korban pesuruh langsung memegang/menahan agar tidak terjadi perkelahian, karena mereka menghormati pesuruh besar.

4. Kepala-kepala suku, tua-tua adat, tokoh-tokoh agama, dan masyarakat adat semuanya diatur dan duduk di belakang.

Peran utama para-para adat atau lembaga masyarakat adat Nafri dalam menyelesaikan perkaraperkara yang terjadi di masyarakat adat kampung Nafri yaitu, menjadi fasilitator dengan menampung dan menyelesaikan semua keluhankeluhan atau masalah-masalah, aspirasi dari masyarakat tentang adat di kampung Nafri. Dan juga sebagai penegak hukum dalam penyelesaian perkara pidana dan sengketa perdata di masyarakat hukum adat Nafri. Sedangkan fungsi lembaga masyarakat adat Nafri adalah sebagai mediator dalam menyelesaikan perkara tindak pidana dan perdata secara adat.

Bentuk-bentuk penyelesaikan perkara-perkara adat yang terjadi di masyarkat adat Nafri yaitu dengan cara mengumpulkan semua pihakpihak seperti yang tercantum dalam struktur dewan adat Nafri, ketua (Ontofro), kepala-kepala suku, pihak yang berperkara, sekretaris, pesuruh besar dari Ontofro, dan tua-tua adat. Dan yang menjadi pemimpin disini (hakim adat) adalah Ontofro. Dalam penyelesaian disini Ontofro melihat dari tingkat pelanggarannya, bila berat pelanggaran yang dibuat maka berat pula denda atau sanksi yang diberikan dan bila ringan perbuatannya maka ringan juga sanksi yang diberikan. Mengenai denda atau sanksi yang diberikan itu sesuai dengan nilai uang yang beredar di masyarkat, dulu biasanya Rp 100.000,- namun sekarang mencapai jutaan (bila berat pelanggaran yang dibuatnya).

Lembaga adat Nafri dalam menyelesaikan berbagai persoalan 
pidana maupun perdata adat didasarkan atas hukum adat atau norma-norama yang berlaku di masyarakat hukum adat Nafri dengan mengesampingkan hukum Nasional. Ada beberapa jenis-jenis tindak pidana atau pelanggaran adat yang sudah pernah ditangani oleh pengadilan adat atau lembaga adat Nafri, seperti :

1. Tindak pidana kekerasan dalam rumah tangga (KDRT)

Denda yang harus pelaku bayar berupa uang saja, mengenai harga tergantung dari permintaan si korban (istrinya).

2. Tindak pidana perzinahan

Denda yang harus pelaku bayar berupa manik-manik 1 (satu) tali yang isinya 24 buah ditambah uang Rp 1.000.000,-

3. Tindak pidana penghinaan (terhadap wanita dan kepala adat) Denda yang harus dibayar pelaku terhadap wanita yang dihina berupa manik-manik 1 buah dan uang Rp 100.000 - Rp 300.000, namun apabila yang dihina kepala adat (ontofro) dendanya manik-manik 1 tali yang isinya 24 buah dan uang Rp 1.000.000 -
Rp 2.000.000, apabila pelaku berasal dari keturunan atau keluarga ontofro maka denda yang harus dibayar, selain menangkap babi juga dikenakan denda dengan gelang batu.

4. Tindak pidana penganiayaan Dendanya berupa uang, harganya tergantung dari permintaan si korban sesuai dengan kondisi luka yang diakibatkan. Khusus penganiayaan pernah melibatkan Ontofro Sembekra yang bernama Sony Gerson Awi (Alm) kakak dari Bapak Terianus Awi. Dendanya berupa 1 (satu) tali manik-manik 24 buah dan uang Rp.2.000.000,- kalau sekarang mencapai Rp. 6.000.000,-

5. Tindak pidana perkelahian

Dendanya sama seperti tindak pidana penganiayaan. Kasus ini juga pernah diselesaikan oleh 2 keondoafian/ontofro dari warke dan sembekra, karena yang bertikai adalah suku dari warke dan suku dari sembekra.

6. Tindak pidana pencurian

Dendanya berupa uang dan manik-manik, uang yang dibayar tergantung nilai barang yang 
dicurinya. Dalam kasus pencurian yang ditangani oleh lembaga adat Nafri biasanya pencurian babi.

7. Tindak pidana membuka rahasia masyarakat

Kasus ini, pada masyarakat adat Nafri dulu kala, pelaku dihilangkan dengan cara dibunuh di rumah Karwari yaitu rumah adat bagi kaum laki-laki.

8. Tindak pidana pembunuhan

Penyelesaiannya pelaku harus ganti rugi dengan membayar uang (uang kepala/darah), namun tetap diproses oleh kepolisian dan dibawah ke Pengadilan Negeri.

9. Hamil diluar perkawinan

Dendanya jika si laki-lakinya tidak bertanggung jawab untuk mengawini wanita tersebut dia harus membayar sangat mahal, karena nilai kewanitaannya sudah hilang, apalagi kalau wanita tersebut masih dalam bangku pendidikan. Kalau pelaku mau bertanggung jawab maka pelaku serta keluarganya hanya wajib membayar uang muka (uang ketuk pintu).

10. Melarikan seorang perempuan
Kasus ini terjadi di kalangan anak muda (dewasa) yang mau kawin, sanksinya hanya diberitahukan pada kedua orang tua dari laki-laki dan perempuan untuk membicarakan selanjutnya apakah mau dikawinkan atau tidak.

Bentuk yang digunakan dalam sistem penyelesaian perkara adat yang dilaksanakan oleh lembaga masyarakat adat Nafri yaitu dengan cara, apabila ada perkara pidana maupun perdata yang timbul dari warga Warke maka yang akan menyelesaikan dan mengambil keputusan adalah keondoafian (Ontofro) dari Sembekra, begitupun sebaliknya apabila ada perkara pidana maupun perdata yang terjadi di Sembekra, maka yang akan menyelesaikan dan mengambil keputusan adalah keondoafian/ontofro dari Warke. Cara ini dilakukan untuk menghindari terjadinya penyimpangan dan ketidakadilan dalam pengambilan keputusan, maksudnya apabila perkara pidana dan perdata yang timbul dari warga warke dan diselesaikan oleh 
ke ondoafian warke itu sendiri biasanya menimbulkan keberpihakkan dalam pemberian denda/sanksi karena adanya hubungan keluarga antara kepala adat (ontofro) dengan korban maupun pelaku. Begitupun sebaliknya di sembekra.

Disini semua orang terlibat dan memiliki kesempatan untuk memberikan masukan sampai pada pengambilan keputusan (asas demokrasi). Pengambilan keputusan oleh kepala adat dilakukan berdasarkan beberapa pertimbangan, di antaranya:

a. Bentuk atau tingkat kesalahan yang dilakukan

b. Pertimbangan si korban

c. Pertimbangan si pelaku

d. Pertimbangan/masukan kepalakepala suku dan tokoh-tokoh masyarakat setempat.

e. Aturan adat setempat (lembaga masyarakat adat Nafri)

Pelaksanaan putusan hukuman langsung diberikan saat putusan dijatuhkan. Hukuman bagi pelaku tindak pidana adat dalam keputusan adalah berupa denda, denda tersebut memiliki tingkatan-tingkatan. Denda bagi orang yang mempunyai kedudukan dan keturunan sebagai raja di kampung Nafri yaitu suku Awi biasanya kalau denda dalam keramaian diminta menangkap babi. Di bawah tingkatan untuk orang Awi yaitu suku merahabia kalau di werke sedangkan di sembekra yaitu suku fingkreuw, mereka biasanya dikenakan denda dengan manikmanik Nomor 1 dan 2. Sedangkan manik-manik Nomor 3 dan 4 diberikan pada suku hanuebi. Denda juga berupa uang, tergantung masalah pengurusannya.

Dari beberapa jenis tindak pidana di atas yang dianggap paling berat oleh masyarakat adat Nafri yaitu, membawa lari istrinya orang (perzinahan), pencurian babi (berat karena nilainya sangat tinggi), dan penghinaan serta pemukulan terhadap ondoafi/ontofro. Dan yang paling sering terjadi yaitu pemukulan (KDRT dan sesama masyarakat Nafri sendiri).

Dalam penyelesaian perkaraperkara pidana seperti yang telah disebutkan diatas oleh lembaga adat Nafri adalah dengan 
mengedepankan musyawarah dalam pengambilan keputusan. Kedua belah pihak diundang untuk diselesaikan di depan forum yang terbuka untuk umum, setelah mendengarkan keterangan dari kedua belah pihak lalu diambil keputusan sesuai tingkat kesalahannya/pelanggarannya dan diberi sanksi adat dengan membayar sejumlah uang atau denda adat seperti:

1. Manik-manik ada 5 (lima) warna

a. Nomor 1, Biru laut disebut Stra

b. Nomor 2, Hijau disebut Sawo

c. Nomor 3, Putih disebut Nento

d. Nomor 4, Biru susu disebut Sboni

e. Nomor 5, Kuning disebut Hasyre

2. Kapak batu ada 2 (dua) bentuk yaitu, pendek dan panjang disebut Syee

3. Gelang batu disebut Abba (nomor satu dan yang paling mahal)

4. Babi disebut Obho

5. Uang disebut Asbangha/Ofe
Jenis-jenis denda adat di atas biasanya disepakati bersama oleh korban dan pelaku dalam sidang adat, karena jenis-jenis denda adat ini sebagai sarana penyelesaian perkara adat pada umumnya, dan fungsinya sebagai penyeimbang dalam mengembalikan sejumlah nilai adat yang diabaikan. Dalam banyak hal, pemberlakuan denda adat ini justru menjadi jalinan hubungan kekerabatan yang baru antara pihak pelaku dan pihak korban.

Bentuk sanksi yang diberikan oleh ondoafi/ontofro dalam sidang adat terhadap pelaku ditetapkan dan tidak dapat diganggu gugat oleh para pihak yang bertikai, dan korban juga harus menerima besar-kecilnya denda yang dapat diberikan oleh pelaku kepadanya sesuai keputusan ontofro. Di sini ontofro sebagai ketua juga harus melihat status sosial dan kedudukan pelaku di kampung Nafri dalam hal kesanggupan untuk membayar ganti kerugian. Sejauh ini keputusan ondoafi/ontofro dalam sidang adat tidak ada yang berkeberatan baik dari korban maupun pelaku 
semuanya harus taat dan menerima keputusan dari ondoafi/ontofro yang berdasarkan hukum atau normanorma adat Nafri, sebab jika tidak mematuhi keputusan (suara) ondoafi/ontofro maka ada tumbal atau balau pada dirinya dan keluarganya (musibah/bencana dan kesialan). Sebab keputusan atau suara dari ontofro mengandung dan terikat dengan roh-roh nenek moyang dulunya hingga sekarang, sehingga membuat pelaku dan korban tidak boleh melawan atau membantah putusan yang diberikan karena takut mendapat musibah/bencana dan kesialan, sebab putusan ondoafi/ontofro itu sah dan adil. Dampak dari pengenaan sanksi berupa denda yang diberikan adalah perdamaian, dan berwujud kekeluargaan dari pihak yang bertikai. Mereka bukan lagi musuh tapi keluarga, berjabat tangan dan berpelukan. Kemudian dilanjutkan dengan doa bersama, setelah itu korban dan keluarganya menyiapkan makanan dan juga pinang selanjutnya makan bersama.
4. Kendala-Kendala Yang di Hadapi Dalam Proses Penyelesaian Perkara Adat Melalui Para-Para Adat

Kendala-kendala atau hambatan yang sering dihadapi pengadilan adat/lembaga adat Nafri dalam menyelesaikan perkara pidana dan perdata adalah sebagai berikut :

1. Adanya penundaan persidangan karena ketidakhadiran salah satu pihak yang berselisih yaitu pelaku, alasannya karena sakit dan menganggap pihak lain tidak perlu ikut campur dalam penyelesaian masalah yang dihadapi.

2. Tunda juga biasanya dilihat dari bukti (saksi) yang dihadirkan untuk meringankan pelaku. Sehingga harus dibuat perjanjian sebelumnya untuk dilanjutkan kembali persidangannya kapan dilaksanakan. Penundaan sidang biasanya dari pelaku dalam hal pembayaran denda, pelaku biasanya meminta waktu untuk mengumpulkan harta yang akan dibayarnya kepada korban di 
depan meja pimpinan dengan disaksikan ketua (ontofro), wakil ketua, sekertaris, pesuruh besar, kepala-kepala suku, tokoh agama, dan masyarakat setempat.

3. Kendala dari korban yaitu, biasanya dalam kasus kekerasan dalam rumah tangga (KDRT) dan perzinahan korban malu untuk diselesaikan melalui sidang adat karena merupakan aib keluarga, sehingga biasanya diselesaikan dalam satu keluarga atau satu marga.

Dengan demikian hal-hal seperti yang disebutkan di atas sangat menghambat proses penyelesaian perkara melalui peradilan adat di kampung Nafri.

\section{SIMPULAN DAN SARAN}

\section{Simpulan}

a. Dalam penyelesaian tindak pidana yang dilaksanakan berdasarkan peradilan adat masyarakat Nafri disini berperan sebagai fasilitator dan mediator (penengah) dalam menyelesaian perkara-perkara pidana maupun perdata adat. Dan juga menampung semua keluhankeluhan atau masalah-masalah serta mendengarkan aspirasi dari masyarakat tentang adat di kampung Nafri, juga sebagai penegak hukum sesuai dengan hukum atau norma-norma yang berlaku di masyarakat adat Nafri. Dan hukuman berupa denda adat sebagai instrumen dan alternatif dalam penyelesaian perkara tindak pidana adat di lingkungan masyarakat hukum adat Nafri di Kota Jayapura.

b. Kendala dalam penyelesaian perkara melalui peradilan adat Nafri adalah, terkadang adanya penundaan persidangan karena ketidak hadiran salah satu pihak yang berselisih yaitu pelaku dengan alasan sakit dan tidak ingin pihak lain turut ikut campur dalam permasalahan yang mereka hadapi sehingga dapat mempersulit penyelesaian perkara melalui pengadilan adat. Serta bukti (saksi) yang dihadirkan oleh pelaku maupun korban kadang sulit hadir dalam persidangan guna meringankan hukuman bagi pelaku dan 
menguatkan bagi korban. Khusus korban dalam penyelesaian kasus kekerasan dalam rumah tangga dan perzinahan terkadang malu untuk menyelesaikan perkara di lembaga adat karena menganggap suatu aib dalam keluarga, sehingga hanya diselesaikan oleh keluarga saja dalam satu marga atau satu suku.

2. Saran

a. Diharapkan kepada pengadilan/lembaga adat Nafri agar lebih berperan aktif dalam upaya menyelesaikan perkara tindak pidana adat yang terjadi, mengingat masyarakat adat Nafri di Kota Jayapura lebih mengenal cara penyelesaian masalah melalui adat ketimbang melalui jalur hukum nasional (hukum tertulis, Undang-Undang).

b. Disarankan kepada masyarakat adat Nafri agar selalu mendukung eksistensi pengadilan adat/lembaga masyarakat adat Nafri dalam menyelesaikan masalah-masalah tindak pidana adat maupun perdata adat guna terciptanya keamanan dan kesejahteraan masyarakat adat Nafri di Kota Jayapura.

Daftar Pustaka

Abdurrahman, 2003, Peradilan Adat dan Lebaga Adat dalam sistem Peradilan Indonesia, Sarasehan, Mataram.

Hadikusuma, Hilman, 1989, Peradilan Adat Di Indonesia, CV.”Miswar", Jakarta.

Hadikusuma, Hilman, 2003, Pengantar Ilmu Hukum Adat, CV Mandar Maju, Bandung.

Nurcholis, H., 2005, Teori dan Praktek Pemerintahan Otonomi Daerah, Grasindo, Jakarta.

Tim Editor AMAN, 2003, Sistem Peradilan Adat dan Lokal di Indonesia: Peluang dan Tantangan, Aliansi Masyarakat Adat Nusantara, Jakarta. 
Upara, Abdul Rahman, 2011, Jurnal Konstitusi: Eksistensi Putusan Pengadilan Adat di Papua dalam Perpektif asas Ne Bis in Idem, Mahkamah Konstitusi Republik Indonesia, Jakarta.

Setiady, Tolib, 2008, Intisari Hukum Adat Indonesia: Dalam Kajian Kepustakaan, Alfabeta, Bandung.

Sekretariat Jenderal Provinsi Papua, Undang-undang Republik Indonesia Nomor 21 Tahun 2001 tentang Otonomi Khusus bagi Provinsi Рариа, Papua, 2001

Undang-Undang Dasar Republik Indonesia Tahun 1945
R. Sugandhi, KUHP dan Penjelasannya, Usaha Nasional, Surabaya, 1980

Himpunan Peraturan Pelaksanaan Desentralisasi Otonomi Daerah di Bidang Pemerintahan dan Keuangan

Biodata penulis:

Nama : Sara Ida Magdalena Awi Alamat : J1. Dukuh Sari No. 9A Sesetan

No. Tlp : 081248781682

Email : saraveral@yahoo.co.id 